\title{
INFLUENCE OF DIFFERENT AUXILIARY AGENTS OF BIOMECHANICAL PREPARATION IN THE FILLING OF “ARTIFICIALLY PREPARED” LATERAL CANALS
}

\author{
INFLUÊNCIA DE DIFERENTES AGENTES AUXILIARES DO PREPARO BIOMECÂNICO \\ NA OBTURAÇÃO DE CANAIS LATERAIS ARTIFICIAIS
}

Daniela Ribeiro da SILVA ${ }^{1}$, Ivaldo Gomes de MORAES ${ }^{2}$

1- MSc in Endodontics, Bauru Dental School - University of São Paulo.

2- DDS, MSc, PhD, Assistant, Professor of the Department of Restorative Dentistry, Endodontics and Dental Materials, discipline of Endodontics, Bauru Dental School - University of São Paulo.

Corresponding address: Daniela Ribeiro da Silva - Rua Professor João Wyclif, 255 apt. 1801 - Bairro Gleba Palhano

Cep.: 86050-250 - Londrina - PR - Fone: (43) 3329-8814 $\quad$ (43) 3324-1615 (43) 91018111 - e-mail: daniela@destaknews.com.br

Received: August 4, 2004 - Modification: September 28, 2004 - Accepted: February 92, 2005

\begin{abstract}
$T_{\text {h }}$

Lhe purpose of the present study was to evaluate the influence of some auxiliary agents of biomechanical preparation of the root canal on the filling of artificial lateral canals in extracted human teeth. A total of eighty single-rooted teeth were employed, which were submitted to preparation of three artificial lateral canals in one of the proximal aspects at the cervical, middle and apical thirds, besides one in the buccal aspect. The main canals were prepared by Profile 0.4 rotary instruments through the crown-down technique and irrigated with the irrigants investigated, as follows: Group A - 1\% sodium hypochlorite and final irrigation with trisodium EDTA for 5 minutes; Group B - Endogel (2\% chlorhexidine gel); Group C - Endo PTC and Dakin' s solution and final irrigation with Tergentol- Furacin; and Group D - File Eze. The root canals were obturated by the Tagger's hybrid technique and then radiographed for assessment of the penetration rate of the filling materials in the lateral canals. Analysis of the results demonstrated no statistically significant difference $(p<0.05)$ between the irrigants both to each other and as regards the location (thirds and aspects) of the artificial lateral canals.

Uniterms: Endodontics; Lateral canals; Root canal, irrigation; Root canal, obturation.
\end{abstract}

\footnotetext{
RESUMO

bjetivou-se avaliar a influência de alguns agentes auxiliares do preparo biomecânico do canal radicular, na obturação de canais laterais artificiais em dentes humanos extraídos. Foram utilizados oitenta dentes unirradiculados nos quais, previamente, foram confeccionados três canais laterais artificiais em uma das paredes proximais, nos terços cervical, médio e apical e um canal na parede vestibular. Os canais principais foram preparados com instrumentação rotatória, instrumentos Profile 0.4 , pela técnica rotatória coroa- ápice e irrigados com a substância irrigadora estudada, sendo no grupo A - hipoclorito de sódio a $1 \%$ e irrigação final com EDTA trissódico por 5 minutos; grupo B - Endogel (gel de clorexidina a 2\%); grupo C - Endo PTC e solução de Dakin e irrigação final com tergentol-furacin segundo a técnica de Paiva e Antoniazzi e no grupo D - File Eze. Os canais foram obturados pela técnica híbrida de Tagger e, então, radiografados para a análise das extensões de penetração dos materiais obturadores nos canais laterais. Após a análise dos resultados, conclui-se que não houve diferença estatística significante $(\mathrm{p}<0.05)$ entre as substâncias irrigadoras utilizadas quando comparadas entre si e nem entre os posicionamentos (terços e faces) dos canais laterais artificiais.

Unitermos: Endodontia; Canais laterais; Irrigação do canal radicular; Obturação do canal radicular.
} 


\section{INTRODUCTION}

A hermetic endodontic obturation requires total filling of the main canal as well as of its ramifications, which are often directly responsible for the endodontic failures. The root canal systems present a quite complex anatomy characterized by the presence of lateral and accessory canals and apical delta, among others. Several studies have demonstrated that lateral canals are observed in a remarkable percentage of teeth. Rubach and Mitchel ${ }^{15}$ observed lateral canals in $45 \%$ of 74 teeth investigated, primarily located at the root apical third. De Deus ${ }^{8}$ observed lateral canals in $27.4 \%$ of 1,140 teeth analyzed, being $17 \%$ at the apical third, $8.8 \%$ at the middle third and $1.6 \%$ at the cervical third.

The presence of accessory and lateral canals allows an access to microorganisms and tissue degradation products between the root canal and the adjacent periodontal tissue. Removal of bacteria and necrotic remnants from the interior of the root canals by means of the biomechanical preparation during endodontic therapy is very difficult or even impossible. Therefore, the tridimensional obturation of the root canal system is fundamental, yet it demands the employment of irrigants that are able to promote cleansing of the openings of the canals that constitute the system, leading to filling of all spaces by the filling material.

One fundamental aspect in the root canal preparation is the mechanical action delivered by specific instruments and instrumentation techniques adequate to each particular case. However, regardless of the treatment elected, the selection of effective irrigants is paramount for a satisfactory final outcome.

Many substances have been employed and investigated as adjutants to the biomechanical preparations, including liquid substances with low surface tension or denser substances.

The employment of creams or gels inside the root canals leads to the assumption that their removal might be difficult and thus they might remain on the root canal walls, as observed in 1975 by Zurbridggem, et al. ${ }^{19}$ with employment of the RC-Prep. Based on these facts, the doubt still remains as to whether the incomplete removal of irrigants from root canal dentinal walls might preclude the hermetic sealing of obturation and block the opening of the lateral canals, therefore hindering their obturation.

Such doubts led to the accomplishment of the present study, the objective of which was to evaluate the influence of some substances employed as auxiliary irrigants in the biomechanical preparation on the obturation of artificial lateral canals in human teeth.

\section{MATERIALAND METHODS}

Eighty human extracted single-rooted mandibular premolars were employed. Lateral canals were initially prepared by means of rotary instruments, being one at each root third on one proximal aspect of the root and another at the middle third of the buccal aspect.
These instruments were prepared from \#10 hand files (Maillefer SA, Swiss, imported and distributed by Dentsply Ind e Com Ltd, Petropolis, RJ, Brazil), which were cut at $2.5 \mathrm{~mm}$ from their active points, so as the diameter of the active point would be approximately compatible to a \#15 file and lance-shaped, allowing dentin perforation for preparation of the lateral canals. After cutting, the files were sectioned between the intermediate portion and the blade. These instruments were then covered with Duralay resin and joined to plastic adapters for high-speed burs in order to allow employment with the low-speed handpiece. The location for the perforation was initially marked with a LN bur in low-speed to prevent sliding of the rotary instruments during the initiation of perforation. The lateral canals were prepared with low-speed with isolated straight movements until reaching the empty space of the main canal. This methodology was adapted following Goldberg, Artaza and De Silvio ${ }^{11}$. All teeth were submitted to conventional crown opening and odontometry was visually established with a \#10 or \#15 Kerr file (Maillefer SA, Swiss, imported and distributed by Dentsply Ind e Com Ltd, Petropolis, RJ, Brazil) attached to a stop, which was introduced in the canal until its end could be observed at the apical foramen. The stop was seated on the reference point established and the file was removed from the root canal. The distance between the file end and the stop was then measured for establishment of the total length of the tooth. The working length was established by subtraction of $1 \mathrm{~mm}$ from this measurement.

Instrumentation of all root canals was accomplished with the ENDOMATE appliance (NKS - Nakanishi Inc., Japan) and .04 taper Profile instruments (Maillefer SA, Swiss, imported and distributed by Dentsply Ind e Com Ltd, Petropolis, RJ, Brazil) of the $1^{\text {st }}$ series (15, 20, 25, 30, 35 and $40)$ and $2^{\text {nd }}$ series $(45,60$ and 90$)$ by the crown-down technique.

For root canal instrumentation, the teeth were randomly divided in 4 groups with 20 elements each, according to the irrigants employed during preparation, as follows:

GROUPA: the root canals were irrigated with $1 \mathrm{ml}$ of $1 \%$ sodium hypochlorite (Miyako do Brasil Ind e Com Ltd, Guarulhos, SP, Brazil) by means of Luer Lock hypodermic syringes and \#25-4 cannulae at each change of instrument, and at completion of instrumentation the root canals were filled with trisodium EDTA - (Biodinamica Quim. E Farm. Ltd., Ibipora, PR, Brazil, batch 282/02) for 5 minutes, followed by neutralization with $5 \mathrm{ml}$ of saline solution (LBS-Laborasa ind. farm. Ltd, Sao Paulo, Brazil).

GROUP B: irrigation of the root canals was performed with $2 \%$ chlorhexidine gel (Endogel, Essencial Fharma pharmacy, Endosuporte distributor, Itapetininga, SP, Brazil). This material was inserted up to complete filling of the root canal by means of hypodermic syringes and \#25-5 cannulae, and then instrumentation was initiated. Irrigation with $0.5 \mathrm{ml}$ of saline solution was carried out at each change of instrument. Every time the chlorhexidine gel exhibited a whitish color, irrigation was performed with $1 \mathrm{ml}$ of saline solution, followed by filling with the gel. At completion of instrumentation the root canals were irrigated with $5 \mathrm{ml}$ of 
saline solution (LBS-Laborasa ind. farm. Ltd, São Paulo, Brazil).

GROUP C: the teeth in this group were irrigated with the cream Endo PTC (POLIDENTAL, IND. COM. LTD), which was inserted by means of a hypodermic syringe up to the opening of the root canals and introduced with endodontic files. Thereafter Dakin's solution (Miyako do Brasil Ind e Com Ltd, Guarulhos, SP, Brazil) was dropped until the pulp chamber was filled. Then, instrumentation was initiated and irrigation was repeated at each change of instrument. Final irrigation was performed with Tergentol - Furacin (Inodon, Porto Alegre, RS, Brazil) following the technique described by Paiva and Antoniazzi ${ }^{14}$.

GROUP D: the root canals in this group were irrigated with the chelant and lubricant File Eze (Ultradent Products Inc., Utah, USA.). This material is a gel commercially available in plastic syringes, to which the cannulae are attached for placement of the material inside the pulp chamber. After placement at the opening of the root canal walls, the material was inserted in the root canals by the same instruments employed for preparation, during which irrigation was carried out with $1 \%$ sodium hypochlorite (Miyako do Brasil Ind e Com Ltd, Guarulhos, SP, Brazil) at each change of instrument. At completion of instrumentation, the root canals were irrigated with $5 \mathrm{ml}$ of saline solution (LBS-Laborasa Ind. farm. Ltd, Sao Paulo, Brazil).

The teeth were stored in distilled water up to obturation, separated in recipients labeled according to the group and tooth.

Immediately before obturation, the teeth were dried with absorbent paper points (Tanari Ind. Ltd, Manacapuru, AM, Brazil) compatible with the width of the working length instrument.

Regardless of the group, all teeth were obturated by the Tagger's hybrid technique with gutta-percha points (Tanari Ind. Ltd, Manacapuru, AM, Brazil) and the endodontic sealer Endofill (Dentsply, Petropolis, RJ, Brazil, batch 1785).

Immediately after obturation, the teeth were radiograph to allow future assessment of the presence or absence of filling of the lateral canals. The radiographs were taken frontally to the buccal aspect for observation of the proximal

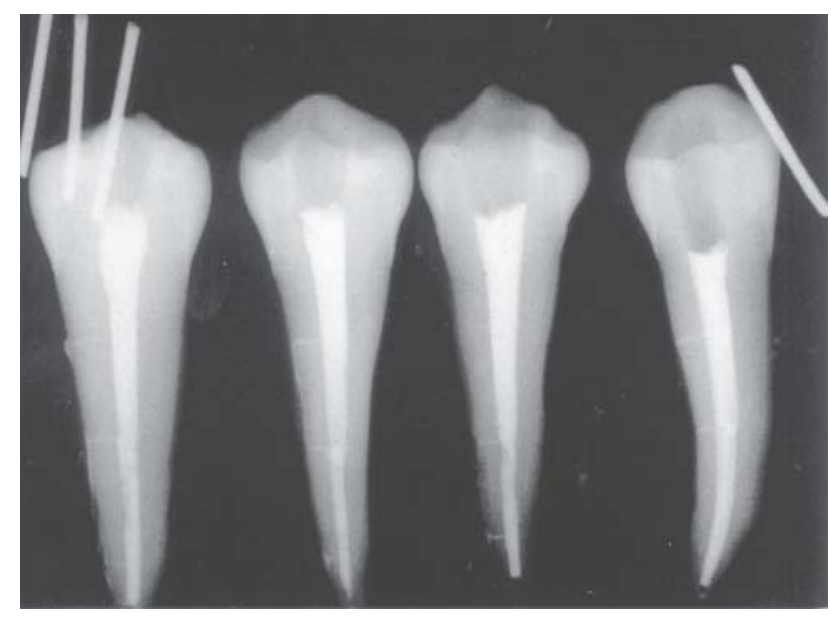

FIGURE 1- Radiograph image of teeth after the filling of the proximal lateral canals lateral canals (Figure 1), and frontally to the mesial aspect for observation of the buccal lateral canals (Figure 2). The radiographs were conventionally developed by the timetemperature technique. All radiographs were simultaneously developed in a dark room.

Analysis of the obturation of the lateral canals was radiographically conducted as follows:

The radiographs were properly arranged in slide mounts and the images were projected for a 10 -fold increase. Measurements were obtained with a millimeter ruler, initially of the total length of the artificial lateral canal and then of the length of filling material penetration inside the artificial lateral canal. The data were recorded in proper forms.

The results achieved were conventionally tabulated and submitted to statistical analysis by the Friedman and Kruskal-Wallis tests.

\section{RESULTS}

Table 1 demonstrates the mean values (in percentages) of the penetration rates of the filling materials in the lateral canals in relation to their location (aspects and thirds) and to the experimental groups, as well as the median, $1^{\text {st }}$ and $3^{\text {rd }}$ quartiles according to the Friedman test.

Comparison between the four locations (thirds and aspects) of the lateral canals according to each study group by the Friedman and Kruskal-Wallis tests did not reveal any statistically significant differences $(p<0.05)$ between them.

\section{DISCUSSION}

The ability of obturation of the lateral canals, either in relation to the irrigants or obturation techniques, has been investigated because of the need of hermetic filling of the root canal system, since the success of endodontic therapy seems to be directly related to this fact as well as to the removal of microorganisms that may remain inside the root canal system and thus lead to future treatment failure.

Many studies have been conducted in an attempt to

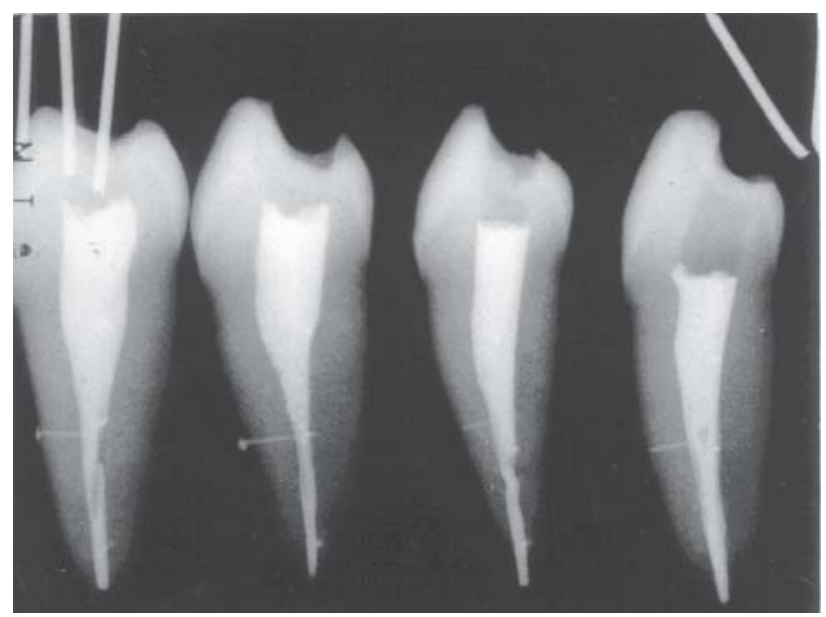

FIGURE 2- Radiograph image of teeth after the filling of the buccal lateral canals 
relate the presence or absence of smear layer and the success of endodontic therapy, such as Economides, et al. ${ }^{9}$ Behrend, et al. ${ }^{3}$ Sen, Wesselink and Turkun, ${ }^{16}$ Dautel-Morazin, et al. ${ }^{7}$ Czonstkowsky, et al. ${ }^{6}$ Aun, et al. ${ }^{1}$ These authors observed that the presence of smear layer allows a higher rate of infiltration on the obturation, does not constitute a barrier against the penetration of bacteria inside the dentinal tubuli, and its removal by means of chelants provides more opened dentinal tubuli, with a cleaner surface for the achievement of a hermetic root canal obturation.

This study made use of four different irrigants to assess their influence on the ability of root canal obturation. The results achieved were satisfactory for al groups. Despite the lack of statistical difference, the larger difficulty of cleansing of the root canal walls at the apical third is clearly observed, in agreement with the study of Ciuchi, et al. ${ }^{5}$

Assuming that the employment of creams or gels inside the root canals as adjutants to the biomechanical preparation might impair the movement of debris released by instrumentation and consequently lead to gathering and compactation of such debris, leading to obliteration of the dentinal tubuli and mainly of the openings of the lateral canals, it might be assumed that irrigation with $1 \%$ sodium hypochlorite during the root canal preparation followed by application of EDTA at final irrigation might provide better outcomes (Berbert, Bramante and Bernardineli ${ }^{4}$ ), allowing obturation of more lateral canals. However, this did not occur.

A more detailed analysis of the outcomes demonstrates that Group A (sodium hypochlorite) was somewhat better than Group D (File Eze) just in relation to the lateral canal of the buccal aspect. In this location, Group A was quite close yet not equal to Group C (Endo PTC).
Comparisons between the materials employed in the present study demonstrated no statistically significant differences, in disagreement with most results achieved by other authors, on which the irrigation with sodium hypochlorite followed by EDTA always provided better outcomes (Goldberg and Abramovich ${ }^{10}$, Holland, et al. ${ }^{13}$, Villegas, et al. $\left.{ }^{18}\right)$. Hizatugo, et al. ${ }^{12}$ found good outcomes with employment of Dakin's solution and EDTA for 15 minutes, followed by the Endo PTC group. As regards the employment of this cream, Batista, et al. ${ }^{2}$ achieved better results when the root canal preparation comprised utilization of this cream and final irrigation with $1 \%$ sodium hypochlorite and EDTA for 5 minutes.

It should be highlighted that Simi Junior, et al. ${ }^{17}$ observed superior outcomes with the employment of Endo PTC when compared to the sodium hypochlorite.

Comparison with other groups is precluded by the lack of similar studies in the literature. The $2 \%$ chlorhexidine gel (Group B) revealed the worst outcomes, whereas the File Eze (Group D) demonstrated reasonable results. Its performance might be explained by the presence of EDTA in its composition. This doubt still remains.

\section{CONCLUSION}

Based on the present outcomes and specific conditions of the present study, the following may be concluded:

1. The auxiliary agents of instrumentation did not have any statistically significant influence on the obturation of the artificial lateral canals.

TABLE 1- Mean percentage, median, $1^{\text {st }}$ and $3^{\text {rd }}$ quartiles of penetration of the filling materials in the lateral canals in relation to their location (aspect and third) and the four experimental groups. Friedman test

\begin{tabular}{|c|c|c|c|c|c|}
\hline $\begin{array}{l}\text { ASPECT } \\
\text { THIRD }\end{array}$ & GROUP & MEAN & MEDIAN & $1^{\text {ST }}$ QUARTILE & $3^{\text {RD }}$ QUARTILE \\
\hline & $A$ & 79.0 & 95.4 & 80.4 & 100.0 \\
\hline BUCCAL & $B$ & 71.7 & 100.0 & 47.2 & 100.0 \\
\hline \multirow[t]{3}{*}{ MIDDLE } & $\mathrm{C}$ & 82.5 & 100.0 & 80.0 & 100.0 \\
\hline & $\mathrm{D}$ & 72.3 & 95.1 & 41.7 & 100.0 \\
\hline & $A$ & 82.5 & 100.0 & 79.3 & 100.0 \\
\hline PROXIMAL & B & 79.6 & 100.0 & 78.2 & 100.0 \\
\hline \multirow[t]{3}{*}{ CERVICAL } & C & 93.2 & 100.0 & 89.9 & 100.0 \\
\hline & $\mathrm{D}$ & 91.2 & 100.0 & 93.4 & 100.0 \\
\hline & $A$ & 77.4 & 100.0 & 59.9 & 100.0 \\
\hline PROXIMAL & B & 70.9 & 96.2 & 36.7 & 100.0 \\
\hline \multirow[t]{2}{*}{ MIDDLE } & C & 94.3 & 100.0 & 95.5 & 100.0 \\
\hline & $\mathrm{D}$ & 82.7 & 100.0 & 90.0 & 100.0 \\
\hline PROXIMAL & B & 51.0 & 59.7 & 0.0 & 100.0 \\
\hline \multirow[t]{2}{*}{ APICAL } & $\mathrm{C}$ & 77.8 & 100.0 & 73.2 & 100.0 \\
\hline & $\mathrm{D}$ & 63.2 & 91.7 & 0.0 & 100.0 \\
\hline
\end{tabular}




\section{REFERENCES}

1- Aun CE, Paiva JG, Antoniazzi JH. Avaliação através da microscopia eletrônica de varredura, da limpeza da parede do canal radicular (terço apical), após o preparo químico mecânico, tendo como fonte de variação o tipo e o número de uso de instrumentos. Rev Assoc paul Cirurg Dent. 1990;44:13-7.

2- Batista A, Pesce HF, Bombana AC, Sydney GB. Análise com auxílio da microscopia eletrônica de varredura da limpeza das paredes do canal radicular (terço apical), frente a algumas soluções irrigadoras. Rev Bras Odontol. 1997;54:111-5.

3- Behrend GD, Cuttler CW, Gutmann JL. An in vitro study of smear layer removal and microbial leakage along root-canal fillings. Int Endod J. 1996;29:99-107.

4- Berbert A, Bramante CM, Bernardinelli N. Endodontia prática. São Paulo: Sarvier, 1980

5- Ciucchi B, Khettabi M, Holz J. The effectiveness of different endodontic irrigation procedures on the removal of the smear layer: a scanning electron microscopy study. Int Endod J. 1989;23:21-8.

6- Czonstkowsky M, Wilson EG, Holstein FA. The smear layer in endodontics. Dent Clin North Amer. 1990;34:13-25.

7- Dautel-Morazin A, Vulcain J, Bonnaure-Mallet M. An ultrastructural study of the smear layer: comparative aspects using secondary electron image and backscattered electron image. J Endod. 1994;20:531-4.

8- De Deus QD. Frequency, location and direction of lateral, secondary, and accessory canals. J Endod. 1965;1:361-6.

9- Economides $\mathrm{N}$ et al. Long term evaluation of the influence of smear layer removal on the sealing ability of different sealers. J Endod. 1999;25:123-5.

10- Goldberg F, Abramovich A. Analysis of the effect of EDTAC on the dentinal walls of root canal. J Endod. 1997;3:101-5.

11- Goldberg F, Artaza LP, De Silvio A. Effectiveness of diferent obturation techniques in the filling of simulated lateral canals. J Endod. 2001;27:362-4

12- Hizatugu R et al. Estudo dos efeitos de instrumentação do cana radicular, em três diferentes técnicas através da microscopia eletrônica de varredura. Rev Bras Odontol. 1987;44:10-6.

13- Holland R et al. Efeitos de diferentes preparados à base de EDTA na dentina dos canais radiculares. Rev Fac Odont Araçatuba. 1973; 2:127-31.

14- PAIVA, J. G. ; ANTONIAZZI, J. H. O uso de uma associação de peróxido de uréia e detergente (Tween 80) no preparo químicomecânico dos canais radiculares. Rev Assoc Paul Cirurg Dent. 1973;27(7):416-23.

15- Rubach WC, Michell DF. Periodontal disease, accessory canals and pulp pathosis. J Periodont. 1965;36:34-8.

16- Sen BH, Wesselink PR, Türkün M. The smear layer: a phenomenon in root canal terapy. Int Endod J. 1995;3:141-8.

17- Simi Junior J, Pesce HF, Mediros JMF. Eficácia de substâncias químicas auxiliares na instrumentação de canais radiculares. Rev Odontol Univ São Paulo. 1999;13:153-7.

18- Villegas JC, Yoshioka T, Kobayashi C, Suda H. Obturation of accessory canals after four different final irrigation regimes. J Endod. 2002;28:534-6.
19- Zurbriggen T, Del Rio CE, Brady JM. Postdebridment retention of endodontic reagents: a quantitative measurement with radiopactive isotope. J Endod. 1975;1:298-9. 